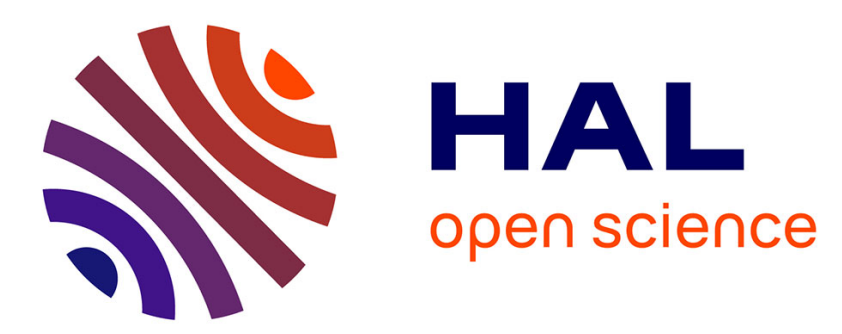

\title{
Dental development pathology in wild artiodactyls: Two prehistoric case studies from France
}

Annelise Binois, Anne Bridault, Gilbert Pion, Thierry Ducrocq

\section{To cite this version:}

Annelise Binois, Anne Bridault, Gilbert Pion, Thierry Ducrocq. Dental development pathology in wild artiodactyls: Two prehistoric case studies from France. International Journal of Paleopathology, 2014, 4, pp.53-58. 10.1016/j.ijpp.2013.11.002 . hal-01673480

\section{HAL Id: hal-01673480 \\ https://hal.science/hal-01673480}

Submitted on 25 Oct 2019

HAL is a multi-disciplinary open access archive for the deposit and dissemination of scientific research documents, whether they are published or not. The documents may come from teaching and research institutions in France or abroad, or from public or private research centers.
L'archive ouverte pluridisciplinaire HAL, est destinée au dépôt et à la diffusion de documents scientifiques de niveau recherche, publiés ou non, émanant des établissements d'enseignement et de recherche français ou étrangers, des laboratoires publics ou privés. 
Case Study

\title{
Dental development pathology in wild artiodactyls: Two prehistoric case studies from France
}

\author{
Annelise Binois ${ }^{\mathrm{a}, \mathrm{b}, *}$, Anne Bridault ${ }^{\mathrm{b}}$, Gilbert Pion ${ }^{\mathrm{c}}$, Thierry Ducrocq ${ }^{\mathrm{d}}$ \\ a Université Paris 1 Panthéon-Sorbonne, UFR03 Archéologie, 3 rue Michelet, F-75006 Paris, France \\ ${ }^{\mathrm{b}}$ CNRS UMR 7041 ArScAn, équipe Archéologies environnementales, 21 allée de l'université, F-92023 Nanterre Cedex, France \\ ${ }^{\mathrm{c}}$ Association départementale pour la recherche archéologique en Savoie, 895 route Bathie des Corniolles, F-73230 Saint-Alban-Leysse, France \\ d INRAP Nord-Picardie, 518, rue Saint Fuscien, F-80000 Amiens, France
}

Keywords:

Animal paleopathology

Prehistory

Cervus elaphus

Sus scrofa

Odontoma

Polydontia

Dental anomalies

\begin{abstract}
A B S T R A C T
In this paper we report two unique cases of dental development anomalies observed on prehistoric faunal material from France. The first is a severely malformed first incisor from a red deer, dated to the 13th-12th millennium BC, which is interpreted as a composite odontoma, a rare pseudo-tumor of odontogenic origin. The second is a Mesolithic (9th-8th millennium BC) wild boar skull presenting an anomalous tooth row including a duplication of the upper left second premolar. Both pathologies are discussed in terms of diagnosis and etiology, and comparable archeological cases are sought. We conclude by stressing that the occurrence of these two developmental anomalies appears to have a strong spontaneous component, and that caution should be exercised when considering such defects in terms of populational significance.
\end{abstract}

\section{Introduction}

Dental development anomalies are among the oral affections frequently encountered in animal paleopathology, and numerous cases have been described in various domestic species (see examples in Wäsle, 1976; Baker and Brothwell, 1980; Miles and Grigson, 1990). Such lesions are however less common in wild animals and are rare for prehistoric times (Fabiš et al., 2008; Gómez-Olivencia et al., 2013). This paper presents two case studies of dental development anomalies in wild artiodactyls, both from prehistoric France: a red deer (Cervus elaphus) composite odontoma and an anomalous tooth row in a Mesolithic wild boar (Sus scrofa).

\section{First prehistoric evidence of composite odontoma in red deer (C. elaphus) from La Fru, France}

\subsection{The case}

The first case originates from the rock-shelter of La Fru, located in Saint-Christophe-la-Grotte in Savoie (French Alps, Fig. 1) and

\footnotetext{
* Corresponding author at: Maison de l'Archéologie et de l'Ethnologie, 21 allée de l'Université, F-92023 Nanterre Cedex, France.

E-mail addresses: annelise.binois@mae.u-paris10.fr, abinois@imacou.net (A. Binois).
}

excavated by G. Pion (Pion et al., 1990). The shelter, located on the eastern edge of the Chartreuse massif $570 \mathrm{~m}$ above sea level, is a limestone overhang under which successive collapses, mostly predating human occupation, have delineated several protected flat areas on which different human groups have settled intermittently from the Magdalenian to the Mesolithic periods. We will focus here on layer $\mathrm{c} 3$, well dated between 12,200 and $11,400 \mathrm{cal}$. BC by multiple consistent radiocarbon dates. This layer has yielded typical Early Azilian lithic industry and vast amounts of well-preserved faunal remains interpreted as butchery and food waste (Pion, 1997). According to preliminary studies, the main hunted species appear to have been red deer and roe deer (Capreolus capreolus) in almost equal parts, along with a few ibex (Capra ibex) and chamois (Rupicapra rupicapra) (Binois, 2012).

The specimen we describe was excavated in this Azilian layer, along with numerous fragmentary animal remains, in a recess under large stone blocks in the Aire I of the shelter. The find is unique on the site, resembling a grossly malformed tooth, in which part of the crown of a ruminant mandibular incisor can be recognized. It was attributed to red deer and identified as a permanent left first incisor on the basis of morphological and metric similarities between the crowns, as illustrated in Fig. 2.

The specimen weighs $2.09 \mathrm{~g}$ and measures $23.2 \mathrm{~mm}$ in its greatest dimension, and appears predominantly constituted of enamel. This tissue forms on the caudal and ventral aspects of the tooth a recognizable, albeit deformed, incisor crown, whereas on the 
F R A N C E

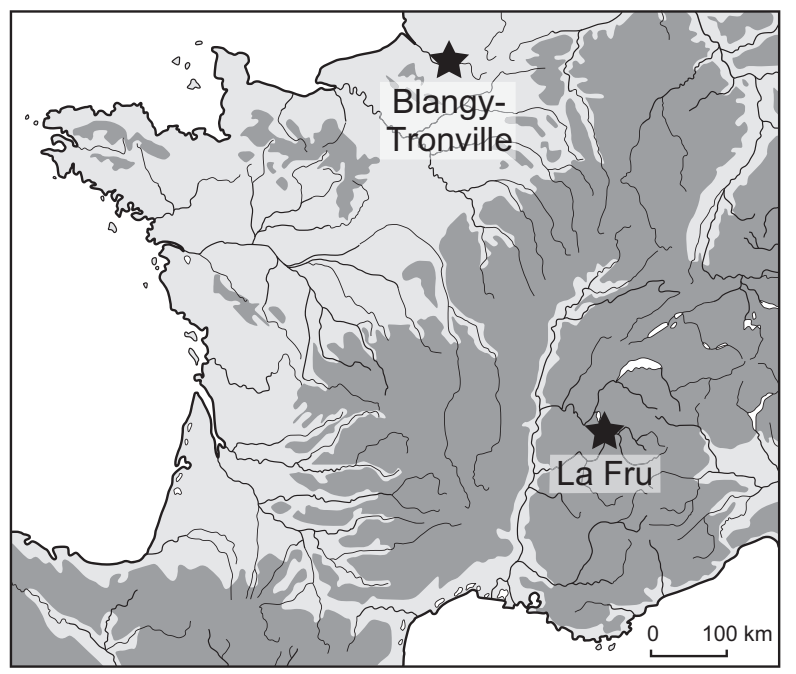

Fig. 1. Location of La Fru and of Blangy-Tronville in France.

mesial side it appears to be a shapeless, rounded lump, especially lingually. No tooth root is present, but a small bulge of a tissue that could be either dentin or cement can be observed on the lingual aspect where the root should be located. On the labial aspect, an irregular mesial cement deposit covers the upper part of the enamel formation. Though histological thin sections would probably have been of great help in the precise identification of the structures involved, none were made because of the small size of the find and of the destructive nature of the analysis. Still, it is notable that at least two, perhaps three typical dental tissues, enamel, cementum and dentin, can be macroscopically identified on the find, although in unconventional locations. The find has thus an odontogenic origin; the differential diagnosis must therefore consider three possibilities: a traumatic malformation, an odontoma and a teratoma.

\subsection{Differential diagnosis}

Trauma to the tooth bud or to a growing tooth is probably the most frequent cause for malformed teeth in both wild and domestic animals (Miles and Grigson, 1990). Two cases can be considered: either the trauma affects the tooth bud and occurs before any mineralization of the crown has begun, or the trauma affects a growing tooth. This second case can be easily excluded here: when trauma occurs on a growing tooth, a pre-traumatic, healthy area can be differentiated on the tooth from the post-traumatic, abnormal zone. As mineralization starts from the top down, the summit of the crown, formed before the trauma, would appear normal; yet our specimen presents clear crown malformation. Therefore, if trauma is to be considered a cause for the malformation, it would have to have affected the tooth bud before mineralization began.

The reference manual by Miles and Grigson (1990) dealing with the diseases of animal teeth presents a great many examples of traumatic malformations of teeth, including several cases in which the trauma occurred before crown mineralization. However, no tooth among those illustrated appears as severely disorganized as our specimen, and almost all present recognizable roots, absent in our find. This absence is, for that matter, perhaps inconsistent with a traumatic origin. The caudal aspect of the tooth crown appears indeed almost normal, and it seems therefore that, if trauma did occur, no serious disorganization of the caudal area of the bud ensued. Yet, if the caudal tooth bud was sufficiently spared from injury as to form a reasonable looking crown, it should also have continued by forming a root, even if partial or deformed. The absence of any sort of recognizable root in our find leads us to consider trauma an unlikely diagnosis, and therefore to examine alternate hypotheses.

Odontomas are odontogenic hamartomas, i.e. non-neoplastic pseudo-tumors of the teeth that cease developing when the affected tissues end their growth (Cawson et al., 1998; Lobprise, 2012). The anarchic growth may affect only one dental tissue, as in enamel pearls or in cement odontomas, or all three tissues, in which case the odontoma is termed composite (Miles and Grigson, 1990; Hillson, 2005). The veterinary literature distinguishes three types of types of composite odontomas: simple odontomas which retain a tooth-like appearance, compound odontomas in which the growth is formed of numerous fused denticles (tiny teethlike formations), and complex odontomas in which the haphazard arrangement of the dental tissues bears no resemblance whatsoever to a tooth. Odontomas can affect all teeth; in humans, preferential locations include the anterior portion of the maxillary arcade (compound odontomas) and the posterior mandible (complex odontomas) (Reichart and Philipsen, 2004). Their etiology is not well understood. They are usually considered to be spontaneous

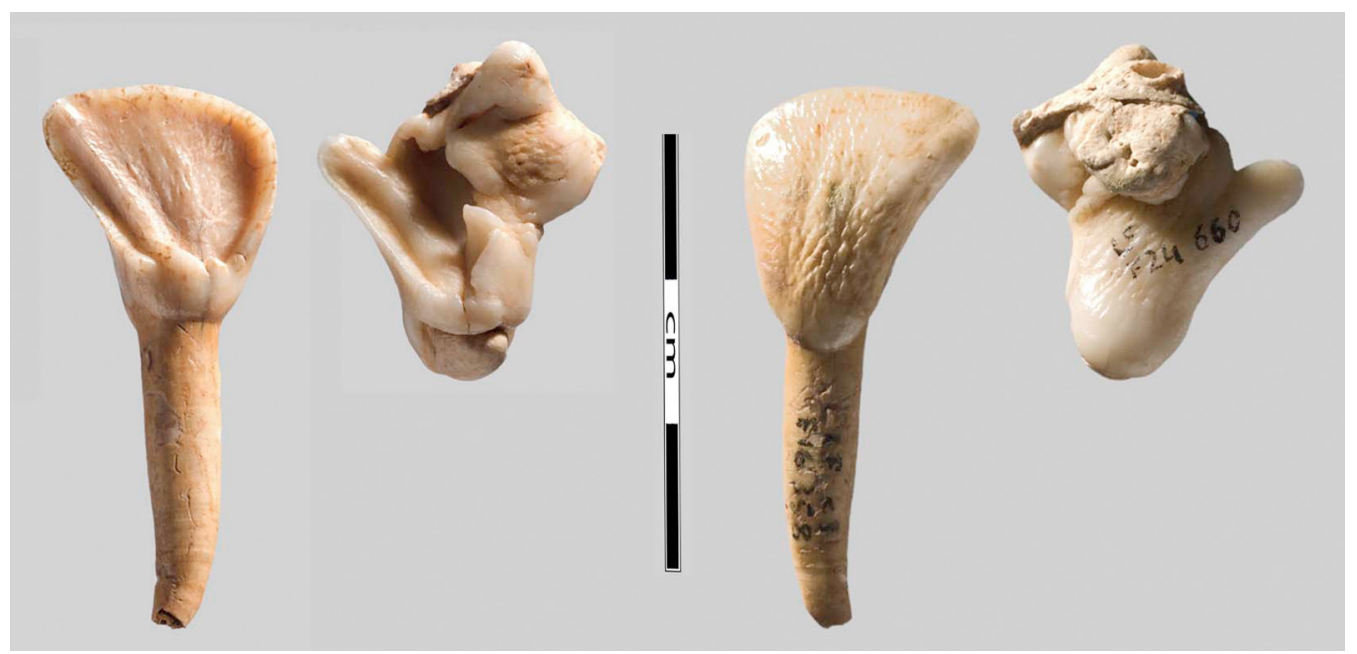

Fig. 2. The odontoma from La Fru, in comparison to a healthy first incisor of red deer from the same archeological level, lingual view and labial view. Photograph S. Oboukhoff. 


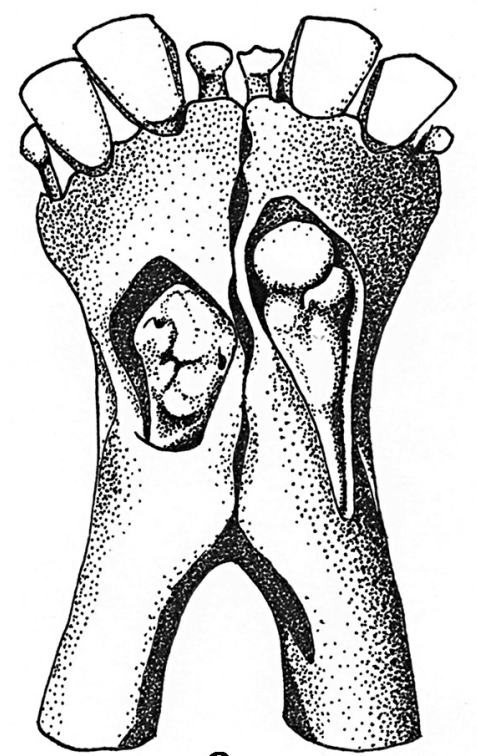

a.

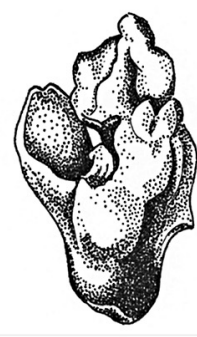

Posterior

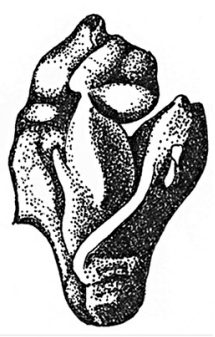

Anterior

b.

Fig. 3. Two modern cases of incisor odontomas, different scales. (a) Bilateral composite odontoma of mandibular first incisor, ox (Bos taurus) and (b) composite odontoma of maxillary second incisor, baboon (Papio papio).

Artwork A. Binois, redrawn from Grigson and Miles (1990).

developmental anomalies, but some authors have suggested infection of the tooth bud as an alternate cause (Reichart and Philipsen, 2004).

Although odontomas can in theory be found in all mammal species, they are always rare affections; in humans, studies showed they represented only $0.4-0.65 \%$ of all specimens submitted for anatomo-pathological analysis (Kaugars et al., 1989; Soluk Tekkesin et al., 2012). They are however probably heavily underdiagnosed in animals, as they most often stay unerupted and can therefore remain unnoticed even in skeletal material. No incisor odontoma has to our knowledge ever been described in cervidae, either extant or fossil, but odontomas of the maxillary molars are known in the genus (Miles and Grigson, 1990). Fig. 3, redrawn from Miles and Grigson (1990), presents two modern cases of incisor odontomas displaying similarities of type and shape with the find from La Fru: a bilateral affection of the mandibular first incisor observed in an ox (Bos taurus) and a composite odontoma of the maxillary second incisor from a baboon (Papio papio).

It is therefore very likely that the find from La Fru can be diagnosed as a composite odontoma of the permanent left first incisor. An alternate hypothesis must however be mentioned: teeth-like formations have exceptionally been described in ectopic locations of the body, associated to tumors known as teratomas (Meuten, 2002). These "dentigerous" teratomas are excessively rare in all species and have apparently never been described in cervids, but could exist nonetheless. Their teeth-like productions can usually not be identified as specific, recognizable teeth, but this eventuality is however theoretically possible, and though very unlikely, the diagnosis cannot be formally ruled out.

\subsection{Consequences of the affection}

If the specimen is an odontoma, its consequences on the health of the affected animal would have varied according to its eruption status. Odontomas are indeed non-cancerous masses that do not in themselves impact upon the general condition of the affected individual and are most often painless, but frequently affect the eruption and positioning of adjacent teeth (Reichart and
Philipsen, 2004; Lobprise, 2012). Red deer are mostly browsing animals that can rely quite heavily on their incisors for the acquisition of food. If the specimen investigated stayed encapsulated within the mandibular bone, such as illustrated in Fig. 4a, the only outer manifestation of the odontoma would have been the absence of the permanent left first incisor, which would probably have had very little to no impact on the animal's browsing abilities. On the other hand, if the odontoma had partly erupted, or even just started

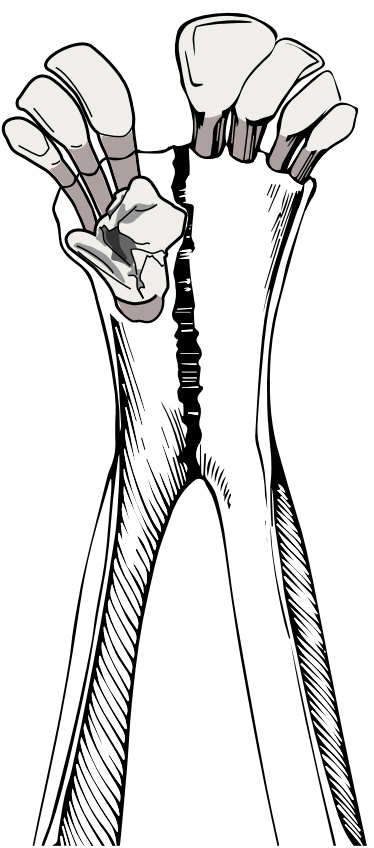

a. Unerupted odontoma

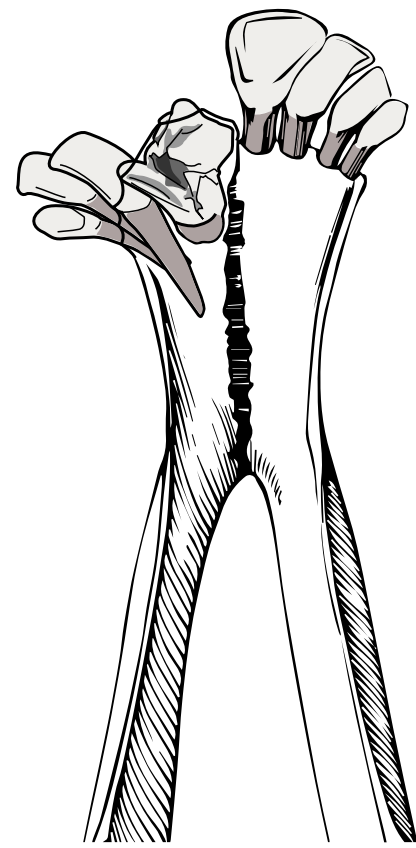

b. Partly erupted odontoma
Fig. 4. Impact of the odontoma: two possible scenarii: (a) unerupted odontoma and (b) part erupted odontoma. CAD A.

Binois, partly redrawn from Pales \& Garcia (1981). 


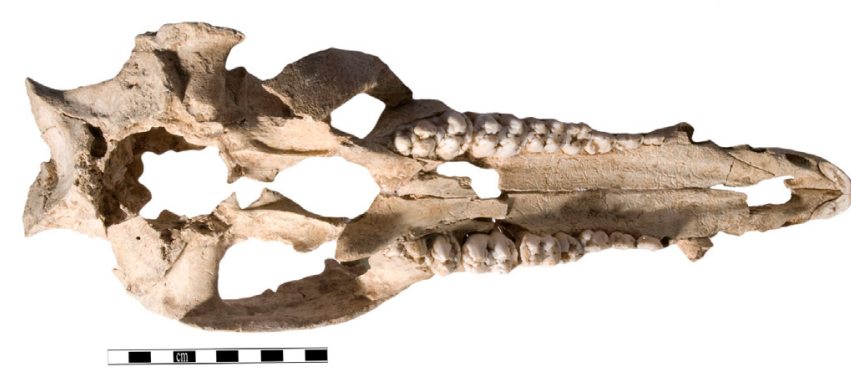

Fig. 5. Sub-complete wild sow skull from Mesolithic Blangy-Tronville, ventral view of maxillary.

Photograph S. Oboukhoff.

migrating toward the alveolar edge of the mandible, its presence would probably have seriously hindered the eruption and positioning of all permanent left incisors, and could have induced a deformation of the left mandible as well. According to the severity of the disturbance, this could have had mild to major impact on the animal's ability to feed itself, and therefore on its general condition; a possible case scenario is illustrated in Fig. 4b.

\subsection{Archeological comparisons}

Odontomas are rare in archeological material, and no case has ever been documented in archeological cervidae either prehistoric or historic. A few occurrences are described in other animal species, including a Gallo-Roman horse (Baker and Brothwell, 1980), a pre-Columbian camelid (Baker and Brothwell, 1980) and several archeological and paleontological proboscidians (Hunter and Langston, 1964; Van Essen, 2004). The high relative frequency of this latter group in the literature is probably strongly related to the sheer size of the finds - one odontoma weighted more than $10 \mathrm{~kg}$ (Hunter and Langston, 1964) - much more than to any particular specific susceptibility to the condition. Odontomas are slightly better documented in human archeological material in which a dozen or so cases have been described (see examples in Brothwell, 1959; Santini, 1987; Anderson and Andrews, 1993; Strouhal, 1998; Djurić and Rakocević, 2007), including an isolated specimen from Mesolithic Belgium (Polet et al., 2004); they remain however very rare finds.

\section{Rare dental anomalies on a wild boar (S. scrofa) from mesolithic Blangy-Tronville, France}

\subsection{The case}

Our second case study presents several dental anomalies, including a dental duplication, observed in the maxilla of a wild boar from a Mesolithic context. "La petite tête" is a Mesolithic open air site located near the edge of a plateau overlooking the Somme valley, in Blangy-Tronville in northern France (cf. Fig. 1). Rescue excavations carried out in 1998 by T. Ducrocq (AFAN) revealed several flint tool surface scatters and a unique pit containing animal butchery waste in close association with lithic artifacts (Bridault, 1998; Ducrocq, 2001) of a Mesolithic industry well documented regionally between 8600 and 7600 cal. BC (Ducrocq, 2009). The faunal remains were well preserved although bone collagen preservation was inadequate for radiocarbon dating (Drucker, pers. commun.). All remains were identified as belonging to wild boar, with a minimum of two individuals present. Among these were the fragmented skull and mandible of a young adult sow (Fig. 5) whose age was estimated between 30 and 36 months according to the dental eruption stages of the upper and lower jaws (Matschke,

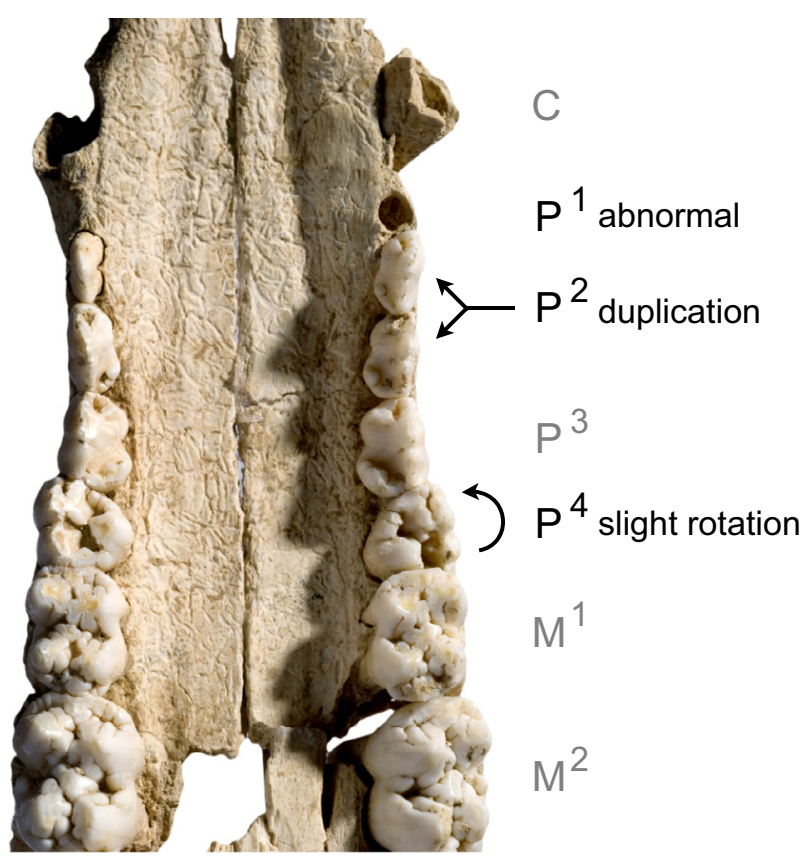

Fig. 6. Anomalous left maxillary tooth row: abnormal socket for $P^{1}$, duplication of $P^{2}$ and rotation of $P^{4}$.

Photograph S. Oboukhoff.

1967; Magnell, 2006). Canine morphology allowed the sexing of the remains.

Despite the fragmentation, the specimen's state of preservation is good. Fragments were glued back together and the skull appears to be sub-complete with all maxillary cheek teeth, excepting the left $P^{1}$, present in situ. The right maxillary tooth row appears in all respects normal; the left tooth row, on the other hand, exhibits several abnormalities, the most notable of which appears to be the presence of five premolars instead of the usual four. The dental arcade displays a duplication of the upper second permanent premolar: two identical teeth are present in alignment on the arcade in place of the $P^{2}$ (Fig. 6). These two $P^{2}$ appear normally conformed; they are of similar length $\left(13.1 \mathrm{~mm}\right.$ for the distal $P^{2}$ and $12.9 \mathrm{~mm}$ for the mesial $P^{2}$ ) and present identical wear stages. The distal $P^{2}$ is wider $(7.8 \mathrm{~mm})$ than the mesial $P^{2}(6.7 \mathrm{~mm})$, but both remain within the normal size range of the tooth.

The tooth row also exhibits two additional lesser anomalies: a slight counter-clockwise rotation of the permanent fourth premolar, and an anomalous monoradicular and peg-shaped socket for the first premolar. The socket displays no sign of healing, which indicates the tooth was lost post-mortem. It was unfortunately not recovered during the excavations, and nothing can therefore be said of the probable malformations it presented. The rotation observed in the left permanent maxillary fourth premolar is probably consecutive to the overcrowding of the dental arcade: as all definitive premolars erupt overall at the same age, a slight reorganization of teeth positioning to allow for the presence of an extra tooth is likely. Rotated teeth are frequently observed in modern wild and domestic pigs. A study by Horwitz and Davidovitz (1992) gives a prevalence of $10 \%$ in wild boar $(N=107)$, and one by Feldhamer and McCann (2004) notes occurrences in $20 \%$ of the wild boar $(N=39)$ and in $10 \%$ of the domestic pigs $(N=30)$ they examined. The rotations were often linked to malocclusion or overcrowding of the cheek teeth.

Only the right mandible of the animal was present in the deposit and displays normal occlusion with the corresponding maxillary row and no particular anomalies. The absence of the left mandible does not allow us to conclude on whether the anomalous maxillary tooth row had an impact on the opposing teeth, but the 
Table 1

Archeological examples of dental duplications in the cheek teeth of pigs and wild boars.

\begin{tabular}{|c|c|c|c|c|c|}
\hline Animal & Period & Location & Md/Max & Duplicated tooth & Reference \\
\hline Pig & Neolithic & Feldmeilen-Vorderfeld, Switzerland & Mandibular & M3 & Wäsle (1976) \\
\hline Pig & Iron Age & Heuneburg, Germany & Mandibular & $\mathrm{P} 2$ & Geringer (1967) \\
\hline Pig & Iron Age & Heuneburg, Germany & Maxillary & $\mathrm{P} 2$ & Geringer (1967) \\
\hline Pig & 1 st. century BC & Manching, Germany & Mandibular & M3 (abnormal) & Meyer-Lemppenau et al. (1971) \\
\hline Pig & 1 st. $1 \mathrm{BC} / 1$ st. $\mathrm{AD}$ & Magdalensberg, Austria & Mandibular & M3 & Luhmann (1965) \\
\hline Pig & Roman & Clermont-Ferrand, France & Maxillary & $\mathrm{P} 2$ & Silvino $(2010)$ \\
\hline Boar & Medieval & Novgorod, Russia & Mandibular & P3 & Zinoviev (2010) \\
\hline Pig & Medieval & Niederrealta, Switzerland & Maxillary & P1 or P2 (abnormal) & Klumpp (1967) \\
\hline Pig & Medieval & East Anglia, UK & Maxillary & $\mathrm{P} 2$ & Rajkovaca, pers. commun. \\
\hline Pig & Medieval & Unterregenbach, Germany & Maxillary & P2 & Schatz (1963) \\
\hline Pig & Post-medieval & Eastern Europe & Mandibular & P2 & Price, pers. commun. \\
\hline
\end{tabular}

good alignment and the regular wear of the teeth make that unlikely.

\subsection{The pathology}

Although every species has a given dental formula, individuals of the species can depart from this generic formula, either by the congenital absence of one or several teeth, termed hypodontia, or by the presence of supernumerary teeth, polydontia. The former, though variable according to species, is often rather frequent, whilst the latter is much rarer (Miles and Grigson, 1990). Two types of polydontia can be distinguished (Wolsan, 1984; Miles and Grigson, 1990). The reoccurrence of an ancestral tooth, lost in the course of phylogeny, is termed atavistic polydontia; such is the case, for instance, in the mandibular first premolar that is sometimes observed in roe deer (Fabiš et al., 2008). The second type of polydontia is dental duplication, in which two identical teeth occur where only one should be found. As suids have the full primitive eutherian dentition of 44 teeth, this latter case seems the only possibility for pigs and boars.

The physiopathological mechanisms of tooth duplication are not well understood (Garvey et al., 1999; Proff et al., 2006; Fleming et al., 2010); authors most often incriminate either a local hyperactivity of the dental lamina resulting in the production of an extra tooth bud or the splitting or dichotomy of an existing tooth bud. Although studies suggest genetic factors may be involved, the condition does not follow a Mendelian inheritance pattern (Fleming et al., 2010), and is probably multifactorial with a strong spontaneous, "accidental" component (Garvey et al., 1999; Proff et al., 2006).

Dental duplication is uncommon but not rare in modern suids; Horwitz and Davidovitz (1992) noted a prevalence rate of about $4 \%$ in a sample of 107 wild boar from Israel, and Colyer noted four

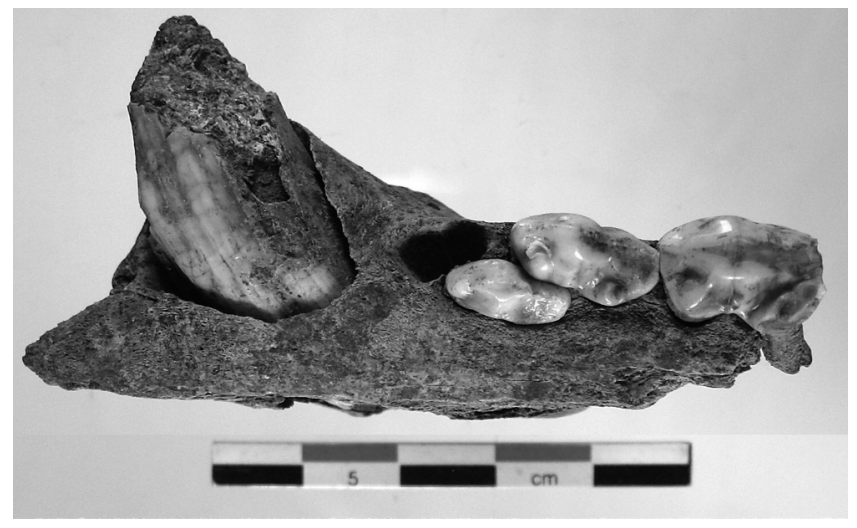

Fig. 7. Duplication and malposition of $P^{2}$ in a domestic pig from Clermont-Ferrand, roman period.

Photograph T. Argant. cases in a study involving 255 skulls of both wild and domestic suids from around the world (1.6\%) (Miles and Grigson, 1990). The tooth the most often affected appears to be the second upper permanent premolar, as in the case presented here. Duplications, both maxillary and mandibular, of other premolars, of the third molar and of the canines have also been documented (Miles and Grigson, 1990; Konjević et al., 2006; Pokorny et al., 2010).

\subsection{Archeological comparisons}

Polydontia has also been described in archeological suids, though never in prehistoric context. A literature review produced one case in a medieval wild boar and nine occurrences in domestic pigs ranging from the Neolithic to the medieval period (Table 1). These cases probably only represent a small sample of all archeological occurrences, many of which remain unpublished. In accordance with modern-day samples, the highest incidence of duplication involves the maxillary second permanent premolar, followed by the mandibular third molar. A case similar to ours and excavated in Roman Clermont-Ferrand (Silvino, 2010) is illustrated in Fig. 7.

\section{Discussion and conclusion}

Dental development anomalies in animals have long aroused interest in zooarchaeology, especially as certain anomalies seem to present higher frequencies in domestic species than in their wild counterparts, and that a genetic transmission can in cases be hypothesized, with mechanisms of founder effect or of co-selection by selective breeding explaining the higher frequencies observed in domestic animals (Baker and Brothwell, 1980; Miles and Grigson, 1990; Hillson, 2005). These observations have however led certain researchers to incorrectly assume all dental development anomalies had a simple genetic origin.

Zinoviev (2010), for instance, notes that "keeping in mind that developmental anomalies are genetically based", a dental duplication observed in a wild boar "can serve potentially in future archeological excavations as an indicator of timely and territorially based particular wild pigs' population." This opinion has already been put into doubt by Gómez-Olivencia et al. (2013), who argue the rarity of the finds would in all cases render the criterion inapplicable in archeological contexts. We would like to further this by underlining the fact that, according to recent medical research (Proff et al., 2006), dental duplications and certain other dental anomalies such as odontomas are multifactorial conditions that appear to have a strong spontaneous component. It therefore seems that much caution should be used when considering dental development anomalies of any type as genetic populational markers, and that other factors, environmental, nutritional or idiopathic, may play as much of a role in the appearance of the disorder. On a side note, the fact that the two cases presented here both stem 
from undoubtedly wild animals should also remind us that dental disorders are not necessarily linked to a domesticated status.

That these disorders may not be genetic do not lessen their value for paleopathology. Rare and unique pathological findings should nonetheless always be reported, being of interest both for archeologists confronted to similar, sometimes baffling finds, and for pathologists working on present-day manifestations of the condition. We must however accept that lesions cannot, unfortunately, be all of populational significance.

\section{Acknowledgements}

This article is an adaptation from a poster presented at the Vth international conference of the ICAZ Animal Palaeopathology Working Group held in Stockholm in June 2013, for which we wish to thank the organizers.

We are grateful to Dorothée Drucker (University of Tuebingen) who did the chemical analysis of a sample of bone collagen from Blangy-Tronville and promptly transmitted us the results. We thank Serge Oboukhoff, of the MAE René Ginouvès, for his superb photographs of the remains. Thanks go as well to Thierry Argant (Archéodunum) for the discussion of a similar case and for the photograph he kindly provided of it. Finally, we would like to thank all members of the ZooArch community who answered our query for similar cases, especially Vida Rajcovaca and Max Price.

\section{References}

Anderson, T., Andrews, J., 1993. A recently excavated odontome from medieval Canterbury, Kent. International Journal of Osteoarchaeology 3 (2), 99-104.

Baker, J., Brothwell, D., 1980. Animal Diseases in Archaeology. Academic Press, London.

Binois, A., 2012. Rapport préliminaire d'étude archéozoologique - La Fru, couche c3, Aire I (Azilien ancien). ADRAS, Unpublished Report.

Bridault, A., 1998. Analyse de la faune du site mésolithique de Blangy-Tronville (Somme). Unpublished Report.

Brothwell, D.R., 1959. A rare dental anomaly in archaeological material. British Dental Journal 107, 400-401

Cawson, R.A., Speight, P., Binnie, W.H., Wright, J., 1998. Lucas's Pathology of Tumors of the Oral Tissues, 5 th ed. Churchill Livingstone, London.

Djurić, M., Rakocević, Z., 2007. Pathology of the mandibles and maxillae from archaeological context: discrepancy between diagnoses obtained by external inspection and radiological analysis. Collegium Antropologicum 31 (2) 379-385.

Ducrocq, T., 2001. Le Mésolithique du Bassin de la Somme. Insertion dans un cadre morpho-stratigraphique, environnemental et culturel. Publications du CERP 7 , Lille.

Ducrocq, T., 2009. Eléments de chronologie absolue du Mésolithique dans le Nord de la France. In: Crombé, P., Van Strydonck, M., Sergant, J., Bats, M., Boudin, M. (Eds.), Chronology and Evolution within the Mesolithic of North-West Europe. Cambridge Scholars Publishing, Newcastle-upon-Tyne, pp. 345-362.

Fabiš, M., Richard, T., Václav, P., Dušan, V., 2008. A development anomaly of prehistoric roe deer dentition from Svodin, Slovakia. In: Miklíková, Z., Thomas, R. (Eds.), Current Research in Animal Palaeopathology. Proceedings of the Second ICAZ Animal Palaeopathology Working Group Conference. BAR International Series 1844. Oxford, pp. 14-18.

Feldhamer, G.A., McCann, B.E., 2004. Dental anomalies in wild and domestic Sus scrofa in Illinois. Acta Theriologica 49 (1), 139-143.

Fleming, P.S., Xavier, G.M., DiBiase, A.T., Cobourne, M.T., 2010. Revisiting the supernumerary: the epidemiological and molecular basis of extra teeth. British Dental Journal 208 (1), 25-30.

Garvey, T., Barry, H.J., Blake, M., 1999. Supernumerary teeth - an overview of classification, diagnosis and management. Journal of the Canadian Dental Association 65 (11), 612-616.

Geringer, J., (Doctoral dissertation) 1967. Tierknochenfunde von der Heuneburg einem frühkeltischen Herrensitz bei Hundersingen an der Donau (Grabungen 1959 und 1963): die Paarhufer ohne die Bovinii. Universität München.

Gómez-Olivencia, A., Arceredillo, D., Rios-Garaizar, J., Garate, D., Iriarte, E., San Pedro, Z., 2013. Dental anomalies in the mandible of Capra pyrenaica: presence of two permanent fourth premolars in a Pleistocene wild goat from Arlanpe cave (Bizkaia, Northern Spain). International Journal of Osteoarchaeology (Preview), http://dx.doi.org/10.1002/oa.1295 (in press).

Hillson, S., 2005. Teeth, 2nd ed. Cambridge University Press, Cambridge.

Horwitz, L.K., Davidovitz, G., 1992. Dental pathology of wild pigs (Sus scrofa) from Israel. Israel Journal of Zoology 38, 111-123.

Hunter, H.A., Langston, W.J., 1964. Odontoma in a northern mammoth. Paleontology 7 (4), 674-681.

Kaugars, G.E., Miller, M.E., Abbey, L.M., 1989. Odontomas. Oral Surgery, Oral Medicine, Oral Pathology 67 (2), 172-176.

Klumpp, G., (Doctoral dissertation) 1967. Tierknochenfunde aus der mittelalterlichen Burgruine Niederrealta, gemeinde Cazis/Graubünden, Schweiz. Universität München.

Konjević, D., Kierdorf, U., Manojlović, L., Severin, K., Janicki, Z., Slavica, A., Reindl, B. Pivac, I., 2006. The spectrum of tusk pathology in wild boar (Sus scrofa L.) from Croatia. Veterinarski Arhiv 76, 91-100.

Lobprise, H.B. (Ed.), 2012. Blackwell's Five-Minute Veterinary Consult Clinical Companion: Small Animal Dentistry. , 2nd ed. Wiley-Blackwell, Ames.

Luhmann, F., 1965. Tierknochenfunde aus der Stadt auf dem Magdalensberg be Klagenfurt in Kärnten: Die Schweineknochen. Verlag des Geschichtsvereines für Kärnten, Klagenfurt.

Magnell, O., 2006. Tooth wear in wild boar (Sus scrofa). In: Ruscillo, D. (Ed.), Recent Advances in Ageing and Sexing Animal Bones. Proceedings of the 9th ICAZ Conference, Durham, 2002. Oxbow, Oxford, pp. 188-202.

Matschke, G.H., 1967. Aging European wild hogs by dentition. Journal of Wildlife Management 31, 109-113.

Meuten, D.J. (Ed.), 2002. Tumors in Domestic Animals. , 4th ed. Wiley-Blackwell.

Meyer-Lemppenau, U., Boessneck, J., Von den Driesch, A., 1971. Die Tierknochenfunde aus dem Oppidum von Manching. Franz Steiner, Wiesbaden.

Miles, A.E.W., Grigson, C. (Eds.), 1990. Colyer's Variations and Diseases of the Teeth of Animals. Cambridge University Press, Cambridge.

Pales, L., Garcia, M.A., 1981. Atlas ostéologique pour servir à l'identification des mammifères du Quaternaire. II. Tête - Rachis, Ceintures scapulaire et pelvienne. In: Herbivores. Editions du CNRS, Paris.

Pion, G., 1997. L'abri de la Fru à Saint-Christophe-la-Grotte (Savoie): l'Azilien ancien du début de l'Alleröd. Bulletin de la Société Préhistorique française 94 (3) 319-326.

Pion, G., Billard, M., Bintz, P., Caillat, B., Cataliotti-Valdina, J., Durand, J.-M., Girard, M., Monjuvent, G., 1990. L'abri de La Fru à Saint-Christophe (Savoie). Gallia Préhistoire 32, 65-123.

Pokorny, B., Poličnik, H., Zaluberšek, M., Konjević, D., Severin, K., Slavica, A., Stergar M., Jelenko, I., 2010. Presence and frequency of different lesions and anomalies of wild boar (Sus scrofa) mandibles in Slovenia. In: 8th International Symposium on Wild Boar and Other Suids, Poster.

Polet, C., Louryan, S., Werquin, J.-P., 2004. A mesolithic case of odontoma? Archives of Oral Biology 49 (6), 501-506.

Proff, P., Fangha, J., Allegrini, S., Bayerlein, T., Gedrange, T., 2006. Problems of supernumerary teeth, hyperdontia or dentes supernumerarii. Annals of Anatomy 188 , 163-169.

Reichart, P.A., Philipsen, H.P., 2004. Odontogenic Tumors and Allied Lesions. Quintessence Publishing, Surrey.

Santini, A., 1987. A compound composite odontoma in a fourteenth century Scottish skull. Paleopathology Newsletter 58, 9-10.

Schatz, H., (Doctoral dissertation) 1963. Die Tierknochenfunde aus einer mittelalterlichen Siedlung Württembergs. Universität München.

Silvino, T. (Ed.), 2010. Puy-de-Dôme (63) - Clermont-Ferrand - 15 et 15 bis, rue sous les Augustins, 3 vol. Archéodunum, Chaponnay (unpublished excavation report).

Soluk Tekkesin, M., Pehlivan, S., Olgac, V., Aksakallı, N., Alatli, C., 2012. Clinical and histopathological investigation of odontomas: review of the literature and presentation of 160 cases. Journal of Oral and Maxillofacial Surgery 70 (6), $1358-1361$

Strouhal, E., 1998. Paleopathological evidence of jaw tumors. In: Alt, K.W., Rösing F.W., Teschler-Nicola, M. (Eds.), Dental Anthropology. Fundamentals, Limits and Prospects. Spinger, Wien, pp. 277-292.

Van Essen, H., 2004. A supernumerary tooth and an odontoma attributable to Mammuthus primigenius (Blumenbach, 1799) (Mammalia, Proboscidea) from The Netherlands, and various related finds. Acta Zoologica Cracoviensia 47 (1-2), 81-121.

Wäsle, R., (Doctoral dissertation) 1976. Gebissanomalien und pathologishanatomische Veränderungen an Knochenfunden aus archäologischen Ausgrabungen. Universität München.

Wolsan, M., 1984. The origin of extra teeth in mammals. Acta Theriologica 29 $128-133$.

Zinoviev, A.V.,2010. A supernumerary permanent mandibular premolar of wild boar (Sus scrofa L.) from the early Medieval Novgorod, Russia. International Journal of Osteoarchaeology 20, 586-590. 